811.163.41'374"18"

https://doi.org/10.18485/msc.2018.47.1.ch14

Ненад Б. ИВАНОВИЋ ${ }^{*}$

Институт за српски језик САНУ Београд
Оригинални научни рад

Примљен: 26. 10. 2017.

Прихваћен: 27. 12. 2017.

\title{
ЛЕКСИКОГРАФСКИ ПОСТУПАК У ОБРАДИ ПРЕФИКСИРАНИХ ГЛАГОЛА У ЈЕДНОМ ИСТОРИЈСКОМ РЕЧНИКУ 19. ВЕКА $* *$
}

\begin{abstract}
У раду се анализира обрада префиксираних глагола у историјском речнику српског језика, са циљем реконструкције научних принципа који су заслужни за организацију тог речника као лингвистичког дела. Анализа се спроводи на материјалу Скуnа ређи'срnски' речи и изреченија (око 1830), рукописног речника непознатог аутора који се чува у Архиву Српске академије наука и уметности. На основу поступака у речничкој обради префиксираних глагола реконструишу се творбено-семантички типови уз помоћ којих аутор речника организује лексичку грађу у оквиру речничког чланка глаголских одредница. Реконструисани творбени типови се затим пореде са Вуковим категоријама које су дате у спису Творба глагола (1832).

Кључне речи: лексикографска историографија, лексикографска теорија, лексикографски поступак, српски историјски речници у 19. веку.
\end{abstract}

\section{1. Увод}

1.1. Задатак и предмет рада. Задатак овог рада је да истражи лексикографске поступке у 19. веку и да каже нешто више о значају тих поступака за развој српске лингвистичке мисли у датом периоду. Анализа се спроводи на материјалу једног рукописног речника из прве половине 19. века. Реч је о Скупу ређи'српски'речи и изреченија, који се чува у Архиву САНУ у Београду (у даљем тексту: „Скуп...”).

*nenad.ivanovic@isj.sanu.ac.rs

** Рад је израђен у оквиру пројекта 178009 Лингвистичка истражсивања савременог српског језика и израда Речника српскохрватског књижевног и народног језика САНУ, који у целини финансира Министарство просвете, науке и технолошког развоја Републике Србије. Овај рад део је ширег истраживања под насловом Лексикографски поступак у историјским речницима 19. века као извор за реконструкиију српске лингвистичке мисли, под којим је изворно пријављен за излагање на 47. Научном састанку слависта у Вукове дане. 
Одлике овог речника детаљно су описане у раду Ивановић 2017 (стр. 78-87), а у закључку истог рада образложен је и значај речника за историју српске лексикографије (стр. 87). Укратко понављамо тамо изложене налазе: 1) спис под пуним називом Скуп ређи' српски' речи и изреченија, понајвише несредственно [непосредно] из разговетни' простака уста [уста простака] брижно и разсудно прибављен представља рукописни речник непознатог аутора од 58 страна текста и око 1800 лексичких уноса. 2) У речнику су излистане речи и изрази са дефиницијама, квалификаторима и примерима. 3) Речник је настао око 1830. године на простору Војводине. 4) У речнику се примарно региструју и описују (раз)говорни изрази који чине део свакодневног живота „обичних, простих” људи са почетка 19. века, а секундарно појмови у енциклопедијском контексту, као и одређени број термина. 5) Обрада лексике у речнику показује високо развијен лексикографски (семантички, творбени, прагматички...) приступ грађи.

1.2. Преглед истраживања. У раду смо анализирали лексикографски поступак у обради префиксираних глагола у „Скупу...”. Обрада ових глагола у речнику се разматра у контексту њихове семантичке и творбене анализе. На основу те анализе утврђена су начела издвајања творбених типова префиксираних глагола. Поменути глаголи су затим смештени у контекст српске лингвистичке мисли прве половине 19. века.

2. У обради префиксираних глагола у „Скупу...” комбинују се два лексикографска поступка.

2.1.1. Први поступак подразумева то да се на левој страни речничког чланка као одредница наведе мотивна основа префиксираног глагола, док се у наставку наводе „изреченија” (типични контексти употребе речи) са глаголима који су изведени од те основе. Тако се, нпр., под словом „К” на одговарајућем месту у речнику наводи глагол куљати са „изреченијем” „Волем и да ми од части искуља (и објашњењем: истресе се, омлати [се]) жито, нег да недозревено буде”. Приказ овог поступка дајемо на следећој слици:

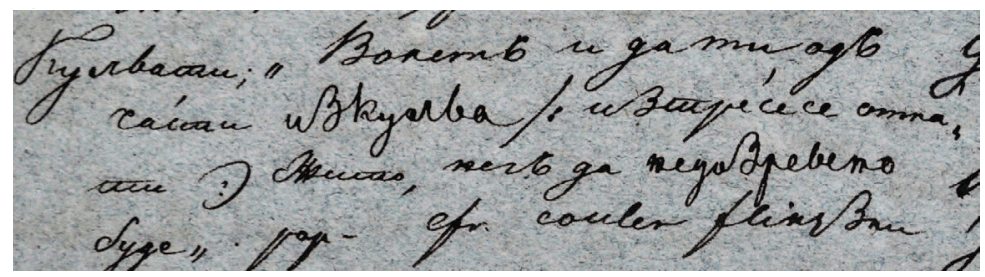

Сл. 1. Обрада префиксираног глагола искуљати у „Скупу...”

2.1.2. Поред глагола, као мотивна основа у оквиру истог поступка у речнику је на месту одреднице давана и именица (за префиксално-суфиксалне творенице). Тако је нпр. мотивна реч вест дата као основа три глагола: навестити (,изреченије” „навестили ... младожењу у цркви”); наговестити (,изреченије” ,,јеси ли му наговестио да не треба дирати”) са имперфектизованом варијантом наговештавати; и обавестити („изреченије” ,једва смо га обавестили”). Приказ овог типа обраде дат је на следећој слици: 


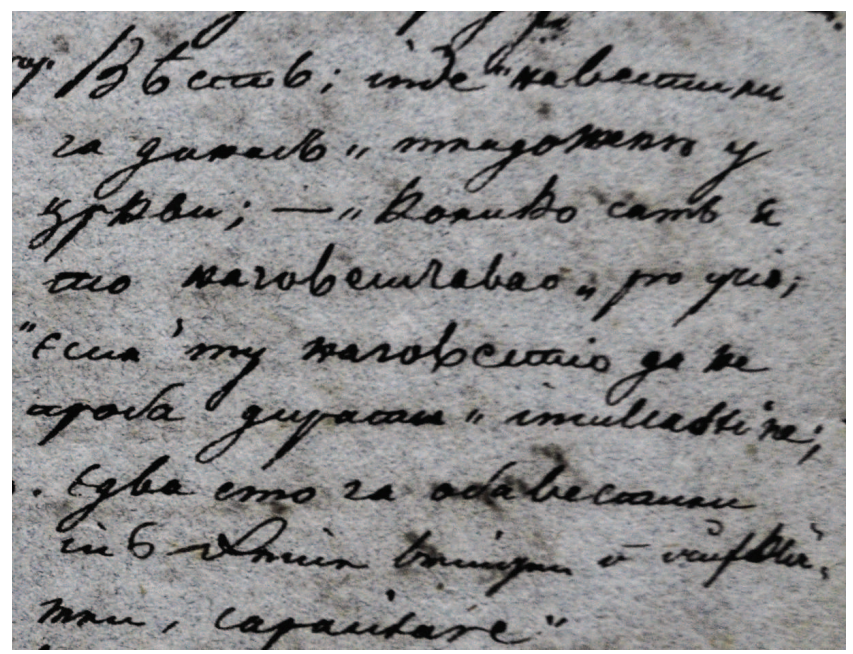

Сл. 2. Обрада префиксално-суфиксалних глагола са мотивном основом вест у „Скупу...”

2.1.3. Формална структура одреднице која је обрађена првим поступком дата је у следећој табели:

\begin{tabular}{|c|c|c|c|c|c|c|c|}
\hline \multicolumn{8}{|c|}{ Структура одреднице } \\
\hline \multirow{6}{*}{$\begin{array}{l}\text { Посту- } \\
\text { пак } 1\end{array}$} & $\begin{array}{l}\text { лематски } \\
\text { унос }\end{array}$ & \multicolumn{3}{|c|}{ „изреченије” 1} & & & \\
\hline & $\begin{array}{l}\text { Гл. } \\
\text { основа }\end{array}$ & $\begin{array}{c}\text { преф. } 1 \\
\text { из- }\end{array}$ & \multicolumn{2}{|c|}{$\begin{array}{l}\text { основа } \\
\text {-куљати }\end{array}$} & & & \\
\hline & Кульати, & \multicolumn{3}{|c|}{$\begin{array}{l}\text { „Волемъ и да ми одъ части } \\
\text { изкульа /:изтресе се, омла- } \\
\text { ти:) жито, негъ да недозре- } \\
\text { вено буде” рор. (...) }\end{array}$} & & & \\
\hline & $\begin{array}{l}\text { лематски } \\
\text { унос }\end{array}$ & \multicolumn{3}{|c|}{ „изреченије” 1} & \multicolumn{3}{|c|}{ „изреченије” 2} \\
\hline & $\begin{array}{l}\text { Им. } \\
\text { основа }\end{array}$ & $\begin{array}{c}\text { преф. } 1 \\
\text { на- }\end{array}$ & $\begin{array}{l}\text { основа } \\
\text {-вест- }\end{array}$ & $\begin{array}{l}\text { суф. } \\
\text {-ити }\end{array}$ & $\begin{array}{l}\text { преф. } \\
2 \\
\text { об-а- }\end{array}$ & $\begin{array}{l}\text { осн. } \\
\text {-вест- }\end{array}$ & $\begin{array}{l}\text { суф } \\
\text {-ити }\end{array}$ \\
\hline & ВЪсть & \multicolumn{3}{|c|}{$\begin{array}{l}\text { „навестили га данасъ” } \\
\text { младоженю у цркви; - }\end{array}$} & \multicolumn{3}{|c|}{ „єдва смо га обавестили” } \\
\hline
\end{tabular}

2.2. Други поступак подразумева то да се на левој страни речничког уноса као одредница наведе цео префиксирани глагол за којим у наставку следи „изреченије” у коме се тај глагол користи. Овај поступак има два подтипа.

2.2.1. У првом подтипу глагол се уазбучава према првом слову мотивне основе (као у пр. глагола облагати у пр. „Об|лагао све људе”). 


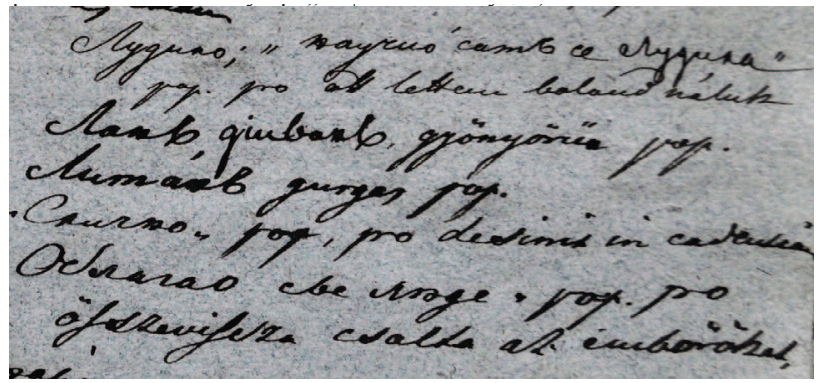

Сл. 3. Унос и обрада глагола облагати у „Скупу...”

2.2.2. У другом подтипу глагол се уазбучава према првом слову префикса (као у пр. гл. искалити: „Искалио срце на њему”). Овај други тип, разумљиво, има вредност само као један од лексикографских поступака примењених у обради префиксираних глагола.

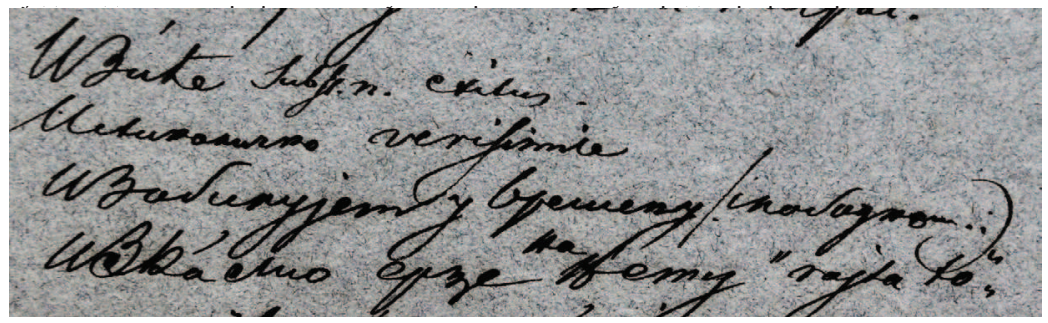

Сл. 4. Унос и обрада глагола искалити у „Скупу...”

2.2.3. Формалну структуру одреднице обрађене другим поступком дајемо у следећој табели:

\begin{tabular}{|c|c|c|c|}
\hline \multicolumn{4}{|c|}{ Структура одреднице } \\
\hline \multirow[t]{6}{*}{ Поступак 2} & \multicolumn{3}{|c|}{ 2. 1. глаголи уазбучени према основи } \\
\hline & $\begin{array}{c}\text { префикс } \\
\text { об- }\end{array}$ & $\begin{array}{c}\text { основа } \\
\text {-лагати }\end{array}$ & \\
\hline & \multicolumn{2}{|c|}{ (Л) Об|Лагао } & све људе \\
\hline & \multicolumn{3}{|c|}{ 2. 2. глаголи уазбучени према префиксу } \\
\hline & $\begin{array}{c}\text { префикс } \\
\text { ис- }\end{array}$ & $\begin{array}{c}\text { основа } \\
\text {-калити }\end{array}$ & \\
\hline & \multicolumn{2}{|c|}{ (И) Изкалио } & рце на њем \\
\hline
\end{tabular}

2.3. Овакав однос аутора „Скупа...” према префиксираним глаголима доста говори о његовом лингвистичком предзнању. У оба поступка лексикограф препознаје префикс као творбено средство за перфектизацију глаго- 
ла. Са друге стране, сама примена два поступка у обради (који се доследно спроводе кроз грађу) указује на то да је лексикограф сматрао да префикс нема увек исти однос према мотивној речи са којом долази у везу, што даље значи да речи изведене на овај начин немају исти статус у речнику. У случају првог поступка префиксирани глагол представља варијацију мотивне речи у контексту „изреченија”. У случају другог поступка изведеном глаголу се признаје статус засебне лексеме. Та лексема задржава везу са мотивном основом (као у пр. гл. облагати) или се развија у засебну, лексичку реч (као у пр. гл. искалити).

3.1. Имајући све ово у виду поставља се питање: постоје ли, и, ако постоје, у чему су разлике између глагола који се обрађују првим и другим поступком? Да бисмо то утврдили извели смо следећу анализу. Из „Скупа...” смо издвојили све префиксиране глаголе који се обрађују првим, односно другим поступком. Затим смо ове глаголе груписали према префиксима. Преглед префикса који су активни у творби глагола једне и друге групе дајемо у следећој табели:

\begin{tabular}{|l|l|l|}
\hline Префикс & $\begin{array}{c}\text { Глаголи обрађени } \\
\text { првим поступком (41) }\end{array}$ & \multicolumn{1}{|c|}{$\begin{array}{c}\text { Глаголи обрађени другим } \\
\text { поступком (65) }\end{array}$} \\
\hline до- & долагати & досегнути \\
\hline за- & зацакати & заварати \\
\hline из- & искуљати & искалити \\
\hline на- & навестити & намерити се \\
\hline над- & надвиривати & \\
\hline о- & омедљати (руке) & острвити се \\
\hline об- & & облагати \\
\hline од- & & одмеравати \\
\hline по- & покрпьати & повладити \\
\hline пре- & & преодолети \\
\hline при- & придржати & привредити \\
\hline про- & прогағати & прозлити се \\
\hline раз- & раскокати се & разлишити \\
\hline с- & сјахати & свабити \\
\hline $\mathbf{y - ~}$ & упетљати & увргути \\
\hline уз- & узјашити & узрогобатити \\
\hline
\end{tabular}


3.2. Из табеле је видљиво да је већина префикса активна у творби глагола обе групе. Разлика је у префиксу над- који се јавља само у првој групи, односно, у префиксима об-, од- и пре- који су присутни само у другој. Разлика у значењу ових префикса може послужити као основ за претпоставку о разликама између глагола прве и друге групе, засновану на опису наведених префикса код неких савремених аутора. Тако нпр. према речима И. Грицкат (1966), префикс над- у творби глагола представља средство чисте (граматичке) перфективизације (стр. 202), што је у грађи потврђено глаголом надвиривати (имперфектизована варијанта гл. надвирити од основе вирити). Са друге стране, семантика префикса об- и пре-, према истој ауторки, пријемчивија је за развој засебних семантичких варијетета глагола (стр. 204-205; 215). Такви варијетети су нпр. у „Скупу...” забележени примери преодолети (од основе гл. одолети, са екцесивним значењем), или облагати (са фактитивним значењем). Према томе, првим поступком у „Скупу...” били би обрађени глаголи који префиксалном перфектизацијом чувају значење основе, а другим поступком глаголи који је овом перфектизацијом мењају.

4. Ову претпоставку проверили смо упоредном анализом глагола који су обрађени једним и другим поступком. За потребе овог излагања анализирали смо глаголе који се граде префиксима за- и раз-.

4.1.1. Префикс за-. У „Скупу...” се налазе следећи случајеви обраде глагола са префиксом за-:

\section{Поступак 1}

Џакати „Заџакали сте децо” (...); Заџакала деца

Метнути - измето се на оца, заметла се кавга

Јазъ - ,других се тамо заязио” рор. рго увалио, уврго у добро.

\section{Поступак 2}

(Г) За|Горчати, рор. „и ово ће загорчати” pro присешће намъ /:трговина:)

(В) За|варали ій /:у рату:) уч. (...)

(М) ,За|метнути зло”

(Н) За|Новетати ... ни је јоште снео снопове /:на њиви у Стави:) рор.

(П) За|премити, и За|премати место рор. „што Запремаш место”, idem мало места запрема ocupat fr. pemere

(П) За|пети, ,ту мораш запети ту ствар” pop. (...)

(T) За|тећи се, pop. ,ja се ту затекао” pro quius нашо, трефио сам бити.

4.1.2. У творби глагола, префикс за- има два значења која се обично повезују са перфектизацијом као граматичком функцијом: ЗАЛАЖЕњЕ ИЗА ОБЈЕКТА ОЗНАЧЕНОГ ГЛАГОЛОМ, И ЗАУСТАВЉАњЕ, ОДН. ФИКСИРАњЕ НЕКОГ СТАњА (ГрИЦКаТ 1966: 208-209). Друго значење (са компонентом почетносвршености) присутно је код глагола прве групе: зацакати (од основе цакати у два „изреченија”) и заметнути се (од основе глагола метнути у значењу „денути се”). Појачана резултативност присутна је у значењу глагола зајазити се, који представља префиксално-суфиксалну твореницу у значењу „задовољити се, заситити се” добијену метафоричним проширивањем основе јаз у значењу отвор, зев (в. јаз у РСАНУ 6.). 
4.1.3. Карактеристично за део глагола друге групе јесте то да у процесу префиксације добијају резултативно значење. Тако нпр. гл. загорчати, од глагола промене укуса, обогаћује своје значење компонентом узроковања која се може формулисати као учинити (нЕшто) тЕшким, НЕподношљивим (,и ово ће загорчати"). Узрочна компонента УПОтРЕБОм ЛУКАВСТВА СПРЕчИТИ, ОМЕСТИ НЕКОГА У НАМЕРАМА (РСАНУ 3.) пристуна је код глагола заварати као типичног глагола узроковања интелектуалних, менталних процеса („заварали их у рату"). Код глагола заметнути у споју са именицом зло као допуном присутна је компонента изАЗиВАњЕ сукоБА. Будући да се глагол заметнути јавља у обе групе, у вези са његовом обрадом у „Скупу...” треба споменути још нешто важно. Запажамо да лексикограф првим поступком обрађује овај глагол у деагентизованој употреби и пасивном значењу, док другим поступком обрађује глагол који је транзитиван и има активно значење. Ово упућује на претпоставку да лексикограф као критеријум за процену врсте перфективизације глагола узима контекст његове реализације, односно, да сматра како је употреба глагола заметнути обичнија у пасивном (заметнути се у значењУ НАСТАТи) него у агентивном и транзитивном контексту (заметнути нешто У значењУ изАЗВАТИ НЕшто).

4.1.4. У оквиру другог поступка у речнику се обрађују глаголи код којих је везу између мотивне речи и изведенице могуће утврдити само етимолошки. Такви су глаголи „везане основе”" зановетати (према Етимолошком речнику П. Скока, од основе новет у значењу „завој, кривудање”) и запремати (према истом извору, од основе предлога према) (Скок 1971-1974, в. те одр.). Ни код глагола запети (од основе глагола петu) и затећи се (од основе глагола тећu) не постоји системско значење префикса (тако за глагол затећu И. Клајн тврди да се не може сврстати ни у једну категорију глагола са за- у савременом језику) (Клајн 2003르. 254).

4.1.5. Обрада глагола са за- у „Скупу...” према типовима поступака може се формализовати следећом табелом:

\begin{tabular}{|l|l|l|l|}
\hline & \multicolumn{1}{|c|}{ глагол } & \multicolumn{1}{|c|}{ основа } & \multicolumn{1}{c|}{ системско значење } \\
\hline \multirow{5}{*}{ Поступак 1 } & \multicolumn{2}{|c|}{ глаголи који не модификују значење основе } \\
\cline { 2 - 4 } & заџакати & (Џ) џакати & $\begin{array}{l}\text { фиксирање новог } \\
\text { стања - почетносвр. }\end{array}$ \\
\cline { 2 - 4 } & заметнути се & (М) метнути & $\begin{array}{l}\text { фиксирање новог } \\
\text { стања - почетносвр. }\end{array}$ \\
\cline { 2 - 4 } & $\begin{array}{l}\text { зајазити се } \\
\text { (негде, на неком месту) }\end{array}$ & (Ј) јазити & $\begin{array}{l}\text { резултат - заврш- } \\
\text { носвр. }\end{array}$ \\
\hline
\end{tabular}

${ }^{1} \mathrm{O}$ термину „везана основа” и његовој рецепцији у српској лингвистици в. у раду Р. Драгићевић (2015). 


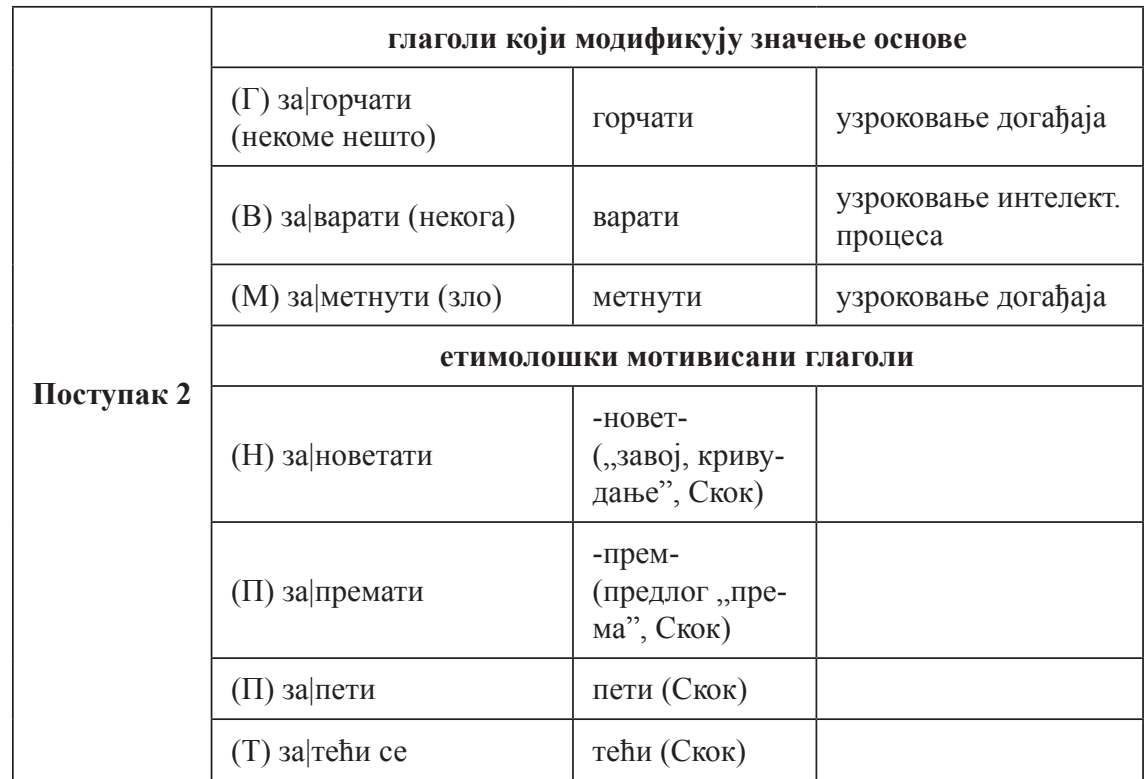

4.2.1. Префикс раз-. У „Скупу...” се налазе следећи случајеви обраде глагола са префиксом раз-:

Поступак 1

Кокати се, „и ти си се нешто мало разкокао” (...)

Пачати се; „непачай се у то” (...) idem ,,разпачао сва своя добра” (...)

\section{Поступак 2}

2.1.

(Д) Раз|друцкаћу те, disuxicam

(Г) Раз|годити idem разгађати рор; покварити и кварити

(Л) Раз|Лишити свой дуг рор. pro deputare abs(olutum?)

(M) Раз|Макни те потоше pop. dimove magis

(Х) Раз|халакала се деца" рор. pro разпустила, обезобразила

(M) Разс|матрати рор. ... disquirere

2.2.

(Р) Разговорити v. pasu кога гођ -

(Р) Разборити, pro разљутити, разјарити човека

(Р) Разчупаће те Јела док чује; (...)

(...)

4.2.2. У творби глагола раз- представља продуктиван префикс. По речима Д. Кликовац, овај префикс сигнализује прелазак објекта из почетног, компактног у завршно, растављено стање, и прецизира оно што се са њим у међувремену догађа. То је његово централно или прототипско значење (Кли- 
ковац 1998: 155). У складу са овим, код глагола обрађених првим поступком префиксација не утиче у већој мери на значење творбене основе, већ га прилагођава прототипском значењу префикса. Тако глагол прве групе раскокати се од основе кокати има ЗНачење СИМЕТРИчНОГ ПОВЕЋАњА ОБИМА ОБЈЕКТА, ДОК глагол распачати се од основе пачати (у значењу „делити”) има значење ПРАВИЛНЕ ДИСПЕРЗИЈЕ ОБЈЕКТА (ИМОВИНе).

4.2.3. Код прве подгрупе глагола који су обрађени другим поступком, префикс знатније мења значење творбене основе. Тако глагол раздрузгати од основе друзгати (,дробити”) има значење РАзБИЈАњА ОБЈЕКТА НА ВИШЕ НЕПРАвилних дЕЛовА. Даље, глагол разгодити од основе годити („погађати посао”, РСАНУ 3.) ИМа ЗНачење ТРАЈНОГ ДЕФОРМИСАњА ИЛИ УНИШТЕњА НЕКЕ ЦЕЛИНЕ (УЗ поништавање значења основе). Глагол разлишити од основе лишити (,ослободити”) има ЗНачење шиРЕњА Или ПОЈАЧАВАњА ОБИМА ОСНОВЕ (,разЛишити ... дуг"), док глагол размакнути има значење дЕљЕњА ОБЈЕКТА НА ДВЕ СИМЕТРИчНЕ цЕлинЕ. Значење глагола разхалакати се од основе $(x)$ алакати може се идентификовати као диспЕРзијА звУкА; а значење глагола разматрати, изведеног (по П. СКоКУ) оД основе гЛ. мотрити, Као ЛОГИЧКО РАШЧЛАњИВАњЕ НЕКЕ ЦЕЛИНЕ.

4.2.4. У другој подгрупи глагола обрађених другим поступком у речнику се налазе глаголи на раз- уазбучени према префиксу: разговорити (некогa) (у зНачењУ изАЗИВАњЕ РАДњЕ); разборити (некога) (у значењУ довоЋЕњЕ У АФЕКТИВНО СТАњЕ); рашчупати (некога) (У значењУ довоЋЕњЕ ДО ПРОМЕНА ФИЗИчког СтАњА). Примери њихове употребе показују да ови глаголи деле једну заједничку одлику, а то је својство каузативне алтернације у самом процесу префиксације. ${ }^{2}$ У њиховој основи налазе се глаголи говорити, борити (се) и чупати који префиксацијом мењају своје контекстуално и рекцијско окружење и постају прелазни перфективни глаголи са компонентом 'узроковање радње'. Префикс раз-, за лексикографа, не служи само као средство перфектизације глагола, већ и као средство промене њихове аргументске структуре и носилац узрочне семантичке компоненте, што се наглашава поступком њихове обраде. Начин уазбучавања глагола овог типа у „Скупу...” сугерише да лексикограф сматра да наведене промене значења и аргументске структуре мотивне основе, када су интегрисане у процес префиксације, предствљају уствари и начин лексикализације.

4.2.5. Обрада глагола са раз- у „Скупу...” према типовима поступака може се формализовати следећом табелом:

${ }^{2} \mathrm{O}$ каузативној алтернацији као виду семантичке творбе в. у раду Ружин Ивановић 2015 (76-83) и у тамо приложеној литератури. 


\begin{tabular}{|c|c|c|c|}
\hline & глагол & основа & системско значење \\
\hline \multirow{3}{*}{$\begin{array}{l}\text { Поступак } \\
1\end{array}$} & \multicolumn{3}{|c|}{ глаголи који не модификују значење основе } \\
\hline & раскокати се & (К) кокати & повећање обима целине \\
\hline & распачати & (П) пачати & $\begin{array}{l}\text { правилна дисперзија } \\
\text { целине }\end{array}$ \\
\hline \multirow{9}{*}{$\begin{array}{l}\text { Поступак } \\
2\end{array}$} & \multicolumn{3}{|c|}{ Подгрупа 1 (уазбучени према основи) } \\
\hline & \multicolumn{3}{|c|}{ глаголи који модификују значење основе } \\
\hline & (Д) раз|друзгати & друзгати & $\begin{array}{l}\text { дисперзија целине на } \\
\text { неправилне делове / } \\
\text { експр. }\end{array}$ \\
\hline & (Г) раз|годити & годити & $\begin{array}{l}\text { трајно деформисање } \\
\text { целине }\end{array}$ \\
\hline & (Л) раз|лишити & лишити & ширење обима целине \\
\hline & (M) раз|макнути & макнути & $\begin{array}{l}\text { дељење целине } \\
\text { (на два једнака дела) }\end{array}$ \\
\hline & (X) раз|халакати се & халакати & дисперзија звука \\
\hline & \multicolumn{3}{|c|}{ етимолошки мотивисани глаголи } \\
\hline & (M) раз|матрати & $\begin{array}{l}\text {-матра- }(\rightarrow \\
\text { мотри-) } \\
\text { (Скок) }\end{array}$ & $\begin{array}{l}\text { рашчлањивање целине } \\
\text { (логичко) }\end{array}$ \\
\hline \multirow{5}{*}{$\begin{array}{l}\text { Поступак } \\
2\end{array}$} & \multicolumn{3}{|c|}{ Подгрупа 2 (по азбучном реду префикса) } \\
\hline & \multicolumn{3}{|c|}{ глаголи као резултат каузативне алтернације } \\
\hline & (Р) разговорити (некога) & говорити & узроковање радње \\
\hline & (Р) разборити (некога) & борити & $\begin{array}{l}\text { узроковање афективног } \\
\text { стања }\end{array}$ \\
\hline & (Р) рашчупати (некога) & чупати & узроковање промене \\
\hline
\end{tabular}

4.3.1. На основу анализе обраде глагола на за- и раз- у „Скупу...” можемо извести следеће опште закључке. Класификација префиксираних глагола у „Скупу...” заснива се на односу између изведене речи и њене творбене основе, а секундарно (код глагола заметнути) и на контексту употребе глаголске лексеме у активу или пасиву. Глаголи у овом речнику се деле на две главне скупине - глаголи који префиксацијом мењају вид, а не и значење (први поступак) и глаголи код којих се префиксацијом модификује значење основе (други поступак). Даље, у оквиру првог поступка се формално одвајају префиксално-суфиксалне творенице, а у оквиру другог поступка се групишу глаголи који у процесу префиксације мењају значење основе и глаголи 
који су сачували још само етимолошку везу између префикса и основе, што сугерише да их аутор посматра као део историјског континуума у префиксалној творби. Обрада ових глагола у савременој лексикографији, описној као и етимолошкој, углавном потврђује тачност анализе у оквиру наведених критеријума.

4.3.2. И друго. Уз регистровање и анализу префиксираних глагола, у „Скупу...” се јавља и лексикографска процена степена њихове лексикализације у односу на категорију у којој се налазе. Најмање лексичким речима сматрају се глаголи који при префиксацији не модификују значење основе. Са друге стране, потпуно лексикализованим речима сматрају се глаголи који током префиксације мењају своју аргументску структуру и значење. Између ова два краја скале (како показује пример глагола заметнути) налазе се глаголи који префиксацијом модификују значење основе.

4.3.3. Све што је изложено може се резимирати следећом табелом:

\begin{tabular}{|c|}
\hline $\begin{array}{c}\text { Поступак } \mathbf{1} \\
\text { 1. глаголи изведени из основе }\end{array}$ \\
\hline - Глаголи који не модификују значење основе (дакати - зауакати) \\
\hline - Префиксално-суфиксалне творенице (јаз - зајазити се) \\
Поступак $\mathbf{2}$ \\
2.1. глаголи уазбучени према основи \\
\hline - Глаголи који модификују значење основе (заварати, разгодити) \\
Етимолошки мотивисани глаголи (запети, разматрати) \\
2.2. глаголи уазбучени према префиксу \\
Поступак 2 \\
\hline - Глаголи настали каузативном алтернацијом (разборити (некога)) \\
\hline
\end{tabular}

5. Лексикографски поступак у „Скупу...” у контексту лингвистичке мисли прве половине 19. века. Издвојеним категоријама и начелима њихове организације, „Скуп...” стоји у одређеном односу према другом важном спису о творби речи из прве половине 19. века. Реч је о „Творби глагола” В. С. Караџића из 1832. (који је, као и „Скуп...”, остао у рукопису). ${ }^{3}$

5.1. О овом Вуковом спису из дериватолошке перспективе писано је у радовима В. Бојић (1977: 168-171) и Б. Ћорића (1988: 196-198). Класификација префиксираних глагола у Вуковом спису заснива се на формалним

${ }^{3}$ Спис „Творба глагола” В. С. Караџића настао је средином 1832. године, готово у исто време када и „Скуп...”. У рукопису је остао до 1984. године, када је објављен у другој књизи Вукових списа о језику и књижевности (Вук 1832 [1986]: 363-431 и 577-581). 
(морфолошким) и семантичким критеријумима. Семантички критеријум обухвата начело творбене мотивисаности глагола, а формални критеријум врсту речи из које је изведен глагол, као и његов флективни наставак (Бојић 1977: 169-170).

5.2. Сажет преглед категоризације префиксираних глагола у спису „Творба глагола" В. С. Караџића дајемо у следећој табели:

\begin{tabular}{|c|}
\hline „Глаголи сложени с једним предлогом” \\
\hline 1. „који се и прости говоре” \\
\hline - (молити - измолити; слобода - ослободити) \\
\hline 2. „који се само сложени говоре” \\
\hline $\begin{array}{l}\text { - Глаголи „изведени од корена (приклопити) } \\
\text { - Глаголи „изведени ... од слогова који сами слабо шта значе” (увалити) }\end{array}$ \\
\hline $\begin{array}{l}\text { - Глаголи „изведени од именица” (зауларити, укоренити) } \\
\text { - Глаголи „изведени од придева” (потуђити се, углачати) }\end{array}$ \\
\hline 3. „који су најпре постали сложени па онда прости” \\
\hline $\begin{array}{l}\text { - Глаголи „изведени од именица” (оженити) } \\
\text { - Глаголи „изведени од придева” (огрубети) }\end{array}$ \\
\hline
\end{tabular}

6. Упоредни преглед односа према класификацији префиксираних глагола у „Скупу...” непознатог аутора (1830) и „Творби глагола” В. С. Караџића (1832) мотивише нас на следећа запажања. У оба списа видљиво је настојање да се глаголи примарно класификују према односу између изведене речи и њене творбене основе. Међутим, док је у „Скупу...” та подела изведена са становишта дијахронијске творбе, као и употребе речи у контексту „изреченија”; у Вуковом спису „Творба глагола” она је спроведена са становишта синхронијске творбе речи. Тако нпр. аутор „Скупа...” из прве групе (глаголи изведени из основе) лексикографским поступком посебно издваја префиксално-суфиксалне творенице, док су код Вука оне дате као део једне општије групе глагола „који се и прости [и сложени] говоре” (Вук 1832 [1986]: 423). Даље, у „Скупу...” је друга група (глаголи уазбучени према префиксу) обрађена као једна формална целина састављена од две подгрупе (глаголи који модификују значење основе и етимолошки мотивисани глаголи). Са друге стране, из комплементарне Вукове групе глагола „који се само сложени говоpe" (Вук 1832 [1986]: 425-429) и формално се издвајају префиксално-суфиксалне творенице од придева и од именица (потуђити се, зауларити и др.). Разлика у приступу грађи код оба аутора најуочљивија је у трећој групи (у „Скупу...”: глаголи настали алтернацијом; код Вука: глаголи „који су најпре постали сложени па онда прости"), будући да ту постоји јасно непоклапање критеријума за класификацију: у првом случају („Скуп...”) реч је о модифи- 
кацији семантике до које долази услед промене рекције; а у другом („Творба глагола") о претпоставци да је префиксирани глагол дуже у употреби него непрефиксирани (нпр. закиселити, продужити и сл.).

7. Поменутим разликама, сагледаним у контексту историјског развоја лингвистичких идеја у српској науци о језику 19. века, требало би посветити даља истраживања.

\section{ИЗВОРИ}

„Скуп...” (око 1830): Непознати аутор, Скуп ређи' Српски'речи и изреченија, понајвише несредственно из разговетни' простака уста брижно и разсудно прибављен, рукопис, Архив САНУ у Београду.

Вук 1832 [1986]: Вук Стефановић Караџић, „Творба глагола”, у: Павић, М. (прир.), Сабрана дела Вука Караџића, књ. 13 (О језику и књижевности II), Београд: Просвета. 362-431 (спис); 577-581 (о спису).

\section{ЛИТЕРАТУРА}

Бојић 1977: Vera Bojić, Jacob Grimm und Vuk Karadzic: ein Vergleich ihrer Sprachauffassungen und ihre Zusammenarbeit auf dem Gebiet der serbischen Grammatik, Munchen: Verlag Otto Sagner.

Грицкат 1966-1967: Ирена Грицкат, Префиксација као средство граматичке (чисте) перфективизације (начелна разматрања и савремена српскохрватска грађа), Јужнословенски филолог, XXVII/1-2, 185-221.

Драгићевић 2015: Рајна Драгићевић, Улога префикса у очувању или потискивању неких прасловенских глагола у савременом српском језику, Cpnски језик, XIX, 235-249.

Ивановић 2017: Ненад Ивановић, Траговима српске лексикографске културе (анализа једног рукописног речника из прве половине XIX века), Къижевност и језик, LXIV/1-2, 77-89.

Клајн 2003': Иван Клајн, Творба речи у српском језику (слагање и префиксаuија), Београд: Институт за српски језик.

Кликовац 1998: Душка Кликовац, О значењу српског глаголског префикса раз-: когнитивнолингвистички приступ, Наш језик, 32/3-4, 153-167.

Ружин Ивановић 2015: Татјана Ружин-Ивановић, Глаголи узроковањ а у енглеском и српском језику (необјављена докторска дисертација одбрањена на Филолошком факултету Универзитета у Београду). 
Скок 1971-1974: Petar Skok, Etimologijski rječnik hrvatskoga ili srpskoga jezi$k a$, I-IV, Zagreb: JAZU.

hорић 1988: Божо Ћорић, Вук и творба речи, Научни састанак слависта у Вукове дане, 17/1, 193-198.

Nenad B. Ivanović

LESXICOGRAPHICAL PROCEDURES IN PROCESSING VERBS WITH PREFIXES FOUND IN ONE MANUSCRIPT DICTIONARY

IN $19^{\mathrm{TH}}$ CENTURY

Summary

In this paper we analyze procedures in processing verbs with prefixes in the manuscript dictionary entitled $A$ Collection of Rarer Serbian Words and Phrases (which is kept in the Archive of the Serbian Academy of Sciences and Arts). 